\title{
Weeksella virosa
}

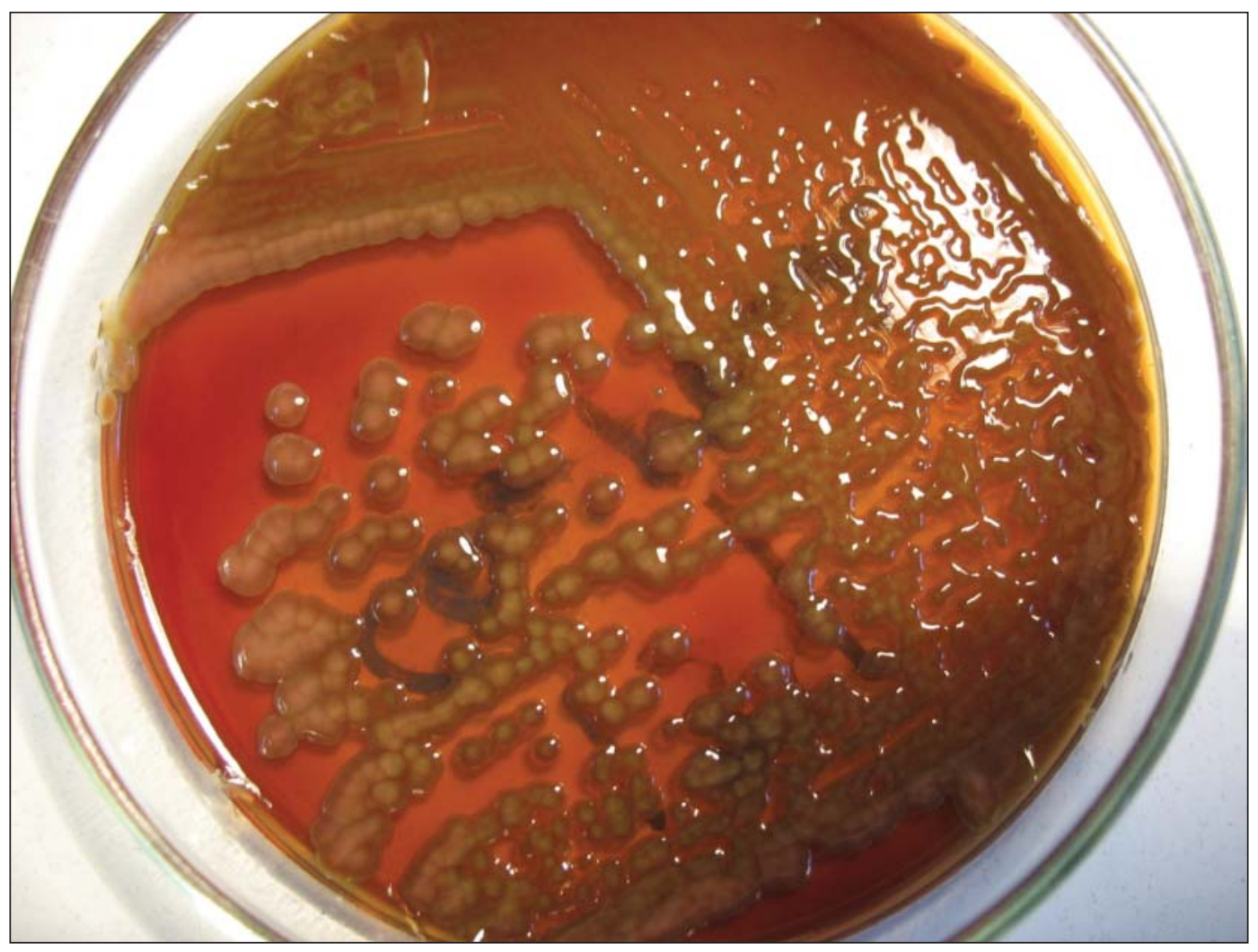

Figura 1. Cultivo de Weeksella virosa a las 48 h de incubación en agar sangre. 


\section{Weeksella virosa}

El género Weeksella, posee una sola especie: W. virosa. Pertenece a la familia Flavobacteriaceae, agrupándose en una de sus ramas conjuntamente con los géneros Empedobacter y Wautersiella, con los que comparte 97 y $98 \%$ de identidad en el gen $16 \mathrm{~S}$ ARNr, respectivamente.

Weeksella virosa ha sido aislada preferentemente en el ecosistema vaginal, siendo descrita en $2 \%$ de las mujeres sin factores de riesgo y en $15 \%$ de las mujeres con riesgo de adquirir infecciones de transmisión sexual. En la Figura 1 se observa una cepa aislada en nuestro laboratorio desde una muestra vaginal de una gestante con microbiota alterada e infección por C. trachomatis. Ha sido descrita esporádicamente en infecciones invasoras, bacteriemia, neumonía y peritonitis. Sin embargo, la literatura científica señala que podría estar siendo sub-diagnosticada, ya que inicialmente las colonias podrían confundirse con Klebsiella, debido a su aspecto mucoso.

Weeksella virosa es un bacilo gramnegativo inmóvil, de 2-3 $\mu \mathrm{m}$ de longitud. A las $24 \mathrm{~h}$ de incubación en agar sangre a $36^{\circ} \mathrm{C}$, da origen a colonias de aproximadamente $2 \mathrm{~mm}$ de diámetro, intensamente mucosas, con aspecto deslizante y color pardo amarillento. Con mayor tiempo de incubación, o conservadas a $4{ }^{\circ} \mathrm{C}$, las colonias van adquiriendo una tonalidad morada a violácea. No crece en agar McConkey.

Bioquímicamente, $W$. virosa es una bacteria aerobia, no sacarolítica, oxidasa y catalasa positiva. Hidroliza la gelatina (24h) pero no la urea, esculina o caseína. Es citrato negativo. En la galería API 20NE (Biomerieux®), es indol positivo, nitrato negativo y no asimila los hidratos de carbono, siendo indistinguible de Empedobacter brevis. No obstante, E. brevis se diferencia fácilmente de Weeksella, por cuanto esta última es sensible a colistin, no utiliza los carbohidratos y no hidroliza la caseína. Es muy sensible a los $\beta$-lactámicos, incluyendo penicilina, es sensible a quinolonas y se caracteriza por ser naturalmente resistente a aminoglucósidos.

\section{Referencias}

1.- Mardy C, Holmes B. Incidence of vaginal Weeksella virosa (formerly group IIf). J Clin Pathol 1988; 41: 211-4.

2.- Manogaran M, Marnejon T, Sarac E. Pneumonia and sepsis due to Weeksella virosa in an immunocompromised patient. Infect Dis Clin Pract 2004; 12: 286-7.

María A. Martínez T. Programa de Microbiología y Micología, Facultad de Medicina Universidad de Chile.

Alfredo OValle $S$.

Servicio y Departamento de Obstetricia y Ginecología, Hospital San Borja Arriarán 